\title{
BERMAIN PERAN (ROLE PLAY) DALAM PEMELAJARAN KETERAMPILAN BERBICARA BAGI PEMELAJAR BIPA TINGKAT PEMULA
}

\author{
Tofan Gustyawan \\ Program Studi Magister Penciptaan dan Pengkajian Seni, Minat Utama Penciptaan Seni Teater \\ Program Pascasarjana Institut Seni Indonesia, Yogyakarta, Indonesia \\ e-mail : tofanoke@gmail.com
}

Diterima : 10 Juni 2019. Disetujui : 5 Agustus 2019. Dipublikasikan : 27 Desember 2019

cC) (7) $\begin{aligned} & \text { C2019 - DESKOVI Universitas Maarif Hasyim Latif. Ini adalah artikel dengan akses } \\ & \text { terbuka di bawah lisensi CC BY } 4.0 \text { (https://creativecommons.org/licenses/by/4.0/) }\end{aligned}$

\begin{abstract}
ABSTRAK
Artikel ini ditulis berdasarkan pengalaman praktis dalam merancang bahan ajar BIPA yang sesuai dengan kebutuhan pembelajar BIPA. Kebutuhan pembelajar yang beragam dapat dijadikan sebagai pertimbangan dalam penyusunan bahan ajar BIPA. Kebutuhan pembelajar harus diketahui agar proses pembelajaran bahasa Indonesia dapat terakomodasi. Pada proses pembelajaran memerlukan pengajar yang kreatif menghadirkan konteks Indonesia dalam proses pemahaman bahasa Indonesia. Pengajar BIPA yang kreatif salah satunya adalah pengajar yang mampu mengaplikasikan kemampuan seni dalam proses pemerolehan bahasa sebagai strategi pembelajaran BIPA.
\end{abstract}

Kata kunci: Bipa, Bermain Peran, Internasionalisasi

\section{ABSTRACT}

This article is written according to practical experience in planning BIPA teaching material which is suitable for BIPA learners' needs. Various learners' needs can be become a consideration in making BIPA teaching material. Learners' need must be known so that Indonesian Language learning process can be accommodated. On learning process is needed a creative teacher whom can bring Indonesian contexts in Indonesian Language comprehension process. One of creative BIPA teachers is a teacher who can apply his art ability in language acquisition process as a strategy in BIPA teaching.

Keyword: Bipa, Role Play, Internasionlize

\section{PENDAHULUAN}

Bahasa Indonesia saat ini semakin diminati oleh beberapa negara sebagai bahasa asing. Ini dikarenakan adanya hubungan internasional antara Indonesia dengan negara lain yang membuka berbagai peluang kerja sama di berbagai bidang seperti politik, ekonomi, sosial, dan budaya. Hal tersebut membuka peluang juga bagi orang asing untuk mempelajari Bahasa Indonesia dengan berbagai tujuan, seperti tujuan akademis dan praktis. Tujuan yang bersifat akademis diarahkan untuk peningkatan pengetahuan kebahasaan dan kesastraan Indonesia, sedangkan tujuan yang bersifat praktis diarahkan untuk keperluan pamrih, misalnya kuliah, penelitian, mengenal budaya, keperluan kerja, ingin tinggal lama di Indonesia, dan lain-lain (Eko Prasetyo, 2015).

Di dalam prosesnya banyak pemelajar asing yang mengalami kesulitan dalam mempelajari Bahasa Indonesia. Pemelajar mungkin sudah memahami konsep dan struktur ketika belajar di kelas, tetapi saat mereka mencoba berkomunikasi di luar kelas, mereka seringkali mengalami kesulitan dalam pemilihan kata atau frasa yang tidak sesuai situasi, sehingga menimbulkan kesalahpahaman. Salah satu contohnya, pemilihan kata yang terlalu baku sehingga komunikasi yang terjadi terkesan canggung. Hal ini terjadi karena pemelajar asing tidak memiliki kepekaan untuk memilih kata sesuai situasi. Kondisi ini wajar karena pemelajar hanya mengetahui suatu kata dan artinya tanpa mengetahui konteks penggunaannya. Menurut Muliastuti (2010), materi yang dikembangkan harus dikaitkan dengan konteks agar bermakna. Oleh karena itu, dalam pengembangan materi harus ada tema yang mengikat keseluruhan materi. Tema-tema harus disesuaikan dengan kompetensi dan kebutuhan pemelajar. Tema yang dirancang harus berawal dari sesuatu yang bersifat konkret hingga bersifat abstrak. Pemberian konteks dan situasi memudahkan pengajar mengintegrasikan berbagai materi.

Di dalam proses pengajaran Bahasa Indonesia bagi Penutur Asing (BIPA), seringkali pemelajar kurang mendapat kesempatan untuk berlatih berkomunikasi. Hal ini membuat pemelajar kurang percaya diri dalam berbicara. Berlatih berkomunikasi berbicara dengan cara meniru pengucapan di kelas 
sangat terasa kaku, bahkan membosankan. Kelas selalu diciptakan dalam situasi membaca dialog saja. Setelah membaca dialog pengajar hanya membahas dialog tanpa menciptakan suasana yang komunikatif.

\section{METODE PENELITIAN}

Penelitian ini menggunakan metode kualitatif dengan pendekatan studi kasus. Tujuan penelitian ini mendeskripsikan penggunaan role play dalam pemelajaran keterampilan berbicara bagi pemelajar BIPA tingkat pemula untuk meningkatkan kemampuan berbicara di kelas BIPA. Salah satu masalah dalam kelas BIPA adalah pemelajar sering mengalami ketidakpercayaan diri ketika berkomunikasi, selain itu pemelajar juga kesulitan dalam pemilihan kata atau frasa yang tidak sesuai situasi, sehingga menimbulkan kesalahpahaman. Salah satu contohnya, pemilihan kata yang terlalu baku sehingga komunikasi yang terjadi terkesan canggung. Hal ini terjadi karena pemelajar asing tidak memiliki kepekaan untuk memilih kata sesuai situasi. Oleh karena itu, penggunaan role play dalam pembelajaran memberi kesempatan tiap individu terlibat dalam komunikasi yang kontekstual. Proses komunikasi dalam role play melatih pemelajar untuk semakin percayadiri menggunakan struktur yang telah dipelajari dan mengembangkanya sesuai dengan pemerolehanya.

Adapun, untuk langkah-langkah penelitian, langkah pertama yang dilakukan adalah melakukan observasi. Observasi dilakukan untuk melihat fenomena apa yang ada di lapangan. Dalam hal ini melihat kondisi di pembelajaran bahasa Indonesia. Hal ini untuk mengetahui di level mana akan diterapkan teknik roll play. Selanjutnya dilakukan persiapan teknik role playing dengan topik yang ditentukan. Selanjutnya, menerapkan teknik role playing tahap I. Sesduah itu, dilakukan analisis pasca-penerapan teknik role playing tahap I ini. Analisis meliputi refleksi pemelajar; kesulitan yang dihadapi pemelajar; dan feedback dari pemelajar berkaitan teknik ini.

Sesudah role playing tahap I, dilakukan role playing tahap II. Selanjutnya dilakukan analisis lagi, yang meliputi progress yang dialami pemelajar. Tahap selanjutnya (tahap III) dilakukan hal yang sama dengan tahap sebelumnya. Sesudah itu dilakukan analisis akhir, dan dlanjutkan dengan validasi.

Selanjutnya, dilakukan revisi. Lalu bisa menarik simpulan dan hasil penelitian. Terakhir pelaporan hasil penelitian. Berikut ini gambaran proses langkahlangkah penelitian.

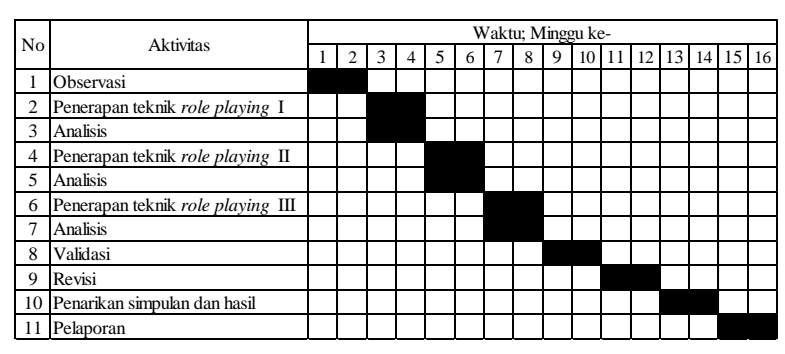

Tabel 1. Proses langkah-langkah penelitian

\section{PEMBAHASAN}

\section{Rencana Pembelajaran BIPA}

Rencana pembelajaran BIPA, merupakan satu hal yang sangat penting oleh pengajar BIPA. Rencana pembelajaran sama seperti pada umumnya, yang membedakanya dalam konteks tulisan ini adalah pembelajaran BIPA di luar negeri. Hal yang perlu dipersiapkan berbeda karena proses pembelajaran akan diadakan di luar negeri. Pengajar dapat mennciptakan proses pembelajaran yang menghadirkan konteks Indonesia dalam proses pembelajaran. Konteks Indonesia yang dimaksud adalah situasi-situasi pemakaian bahasa dalam lingkup budaya. Keterampilan ini sebagai pendukung kemampuan dasar seorang guru BIPA dalam mengembangkan kemampuan berbahasa pembelajar Pembelajaran kontekstual dapat dihadirkan melalui pemahaman bahasa yang terintegrasi dengan pemahaman budaya dan seni. Pengajar BIPA dalam hal ini tidak hanya bekerja dan mengajar bahasa, tetapi juga menjadi agen diplomasi. Sebagai agen diplomasi, guru BIPA diharapkan mampu mengenalkan budaya-budaya di Indonesia. Dengan demikian, tentu diperlukan beberapa hal yang mendukung pembelajaran BIPA. Mengingat umumnya pelajar BIPA adalah orang dewasa (Suyitno, 2007: 63), maka diperlukan metode pembelajaran, media pembelajaran, sarana dan prasarana yang disesuaikan dengan kebutuhan pelajar BIPA.

Dengan demikian perlu adanya persiapan yang matang. Persiapan-persiapan tersebut dapat dilakukan dengan memperhatikan hal-hal yang berkaitan dengan kondisi negara tempat penugasan. Kegiatan yang dilakukan, dibagi dalam kegiatan persiapan pra-penugasan dan kegiatan saat penugasan. Kegiatan pra-penugasan yang akan dilakukan adalah (1) observasi model pembelajaran BIPA untuk mengenal dan mendalami model pembelajaran BIPA yang ada, (2) menyusun RPP sesuai dengan silabus yang sesuai dengan kebutuhan, (3) menyiapkan media untuk mendukung kegiatan pembelajaran, (4) menyiapkan suplemen latihan untuk pemelajar; latihan untuk mendukung empat keterampilan berbahasa (menyimak, berbicara, membaca, menulis), (5) analisis materi dalam buku BIPA untuk melihat materi yang terdapat dalam buku BIPA, (6) menyiapkan metode 
yang efektif untuk setiap topik yang akan diajarkan, (7) menyiapkan penilaian untuk mengukur progres pemelajar, (8) menyiapkan lembar refleksi untuk pemelajar, (9) menyiapkan lembar feedback untuk evaluasi pengajar, (10) menyiapakan informasi kebudayaan untuk setiap pertemuan.

Adapun kegiatan persiapam sebagai berikut, (1) melakukan observasi kelas untuk melihat situasi kelas, (2) melakukan penyisiran kemampuan pemelajar, (3) mengelompokkan pemelajar berdasarkan dingbat kemampuannya, (4) menyiapkan materi dan media, (5) melaksanakan pembelajaran sesuai dengan RPP, (6) memberikan lembar refleksi untuk pemelajar di setiap pertemuan, (7) memberi lembar feedback untuk pengajar di setiap akhir pertemuan, (8) mendokumentasikan kegiatan pembelajaran dalam bentuk jurnal harian, (9) memberi tes untuk melihat progres pemelajar, (10) melakukan analisis kesuliatan yang dihadapi pemelajar, (11) melakukan remedial, (12) pemberian penghargaan untuk pemelajar.

Kegiatan-kegiatan tersebut bukanlah hal yang mutlak untuk dilaksanakan. Perubahan bisa terjadi karena kondisi dan situasi. Namun, dengan adanya perencanaan tersebut, bisa menjadi panduan apa saja yang harus dilakukan selama melaksanakan pembelajaran BIPA di luar negeri.

Salah satu topik kajian yang menarik dalam pembelajaran BIPA adalah teknik pengajaran BIPA. Banyak sekali teknik yang diterapkan oleh pengajar BIPA dalam menyampaikan materi agar pemelajar mampu memahami konsep dan struktur yang diajarkan. Salah satu teknik yang menarik untuk dikaji adalah teknik role playing atau bermain peran. Role playing atau bermain peran adalah sejenis permainan gerak yang di dalamnya ada tujuan, aturan dan sekaligus melibatkan unsur senang (Hadfield, 1986). Di dalam role playing, murid dikondisikan pada situasi tertentu seperti di luar kelas, meskipun saat itu pembelajaran terjadi di dalam kelas. Selain itu, role playing sering kali dimaksudkan sebagai suatu bentuk aktivitas di mana pemelajar membayangkan dirinya seolah-olah berada di luar kelas dan memainkan peran orang lain (Syamsu, 2000). Role play memberikan kesempatan sebanyak-banyaknya kepada pemelajar agar terlibat dalam komunikasi secara aktif.

Role play di dalam kelas BIPA tentunya lebih sederhana dan mementingkan pemahaman kebahasaan. Situasi-situasi yang dihadirkan melalui role play akan mempermudah pemahaman pemelajar terhadap bahasa, karena bahasa diutarakan melalui ekspresi dan konteks. Pengalaman langsung yang dihadirkan melalu role play dapat melatih pemelajar dalam mengkreasikan kata dalam struktur kalimat sesuai imajinasinya. Pengajar juga akan dengan mudah mengamati dan memperbaiki aksen bicara yang dipengaruhi oleh bahasa ibu masingmasing pemelajar. Role play memberi kesempatan tiap individu untuk berlatih pengucapan dengan baik.

\section{Sistematika Role playing di dalam Kelas}

Langkah-langkah bermain peran yang dapat dijadikan pedoman dalam pemelajaran BIPA Sebagian besar role play cenderung dibagi pada tiga fase yang berbeda:

1) Perencanaan Persiapan

Teknik Role play yang digunakan adalah role play sederhana karena tidak membutuhkan banyak persiapan dan mudah dipahami pemelajar. Role play bisa dilakukan sesudah pengajar menyampaikan konsep dan struktur yang menjadi target dalam pembelajaran.

a. Pengajar memilih topik yang sesuai dengan unit pembelajaran dan juga contoh dialog dengan situasi yang konkret.

b. Pada unit pembelajaran tertentu, pemelajar dapat membuat dialog dalam kelompok.

c. Pengajar mengelompokan murid dalam beberapa kelompok berdasarkan kemampuan murid.

d. Pengajar memastikan ruang yang cukup sebelum role play dimulai

2) Pelaksanaan Role Play

Pada tahap pelaksanaan, guru menyiapkan kertas berisi rubrik penilaian.

a. Pengajar mengundi kelompok yang akan role play

b. Pengajar membagikan kertas penilaian kepada pemelajar

c. Kelompok tampil dalam waktu 5-10 menit

d. Kemampuan pemelajar dalam berkolaborasi untuk mengetahui sejauh mana seorang pemelajar memahami struktur kalimat

3) Feedback

Pada tahap ini pengajar memberi apresiasi, umpan balik, serta memberi koreksi terkait struktur kalimat dan ucapan peserta role play.

a. Pengajar mencatat segala hal yang menjadi kendala dan kesulitan yang dihadapi pemelajar.

b. Pengajar memberikan masukan kepada pemelajar.

\section{Fungsi Role Play}

Ada beberapa keuntungan dengan menggunakan metode role playing, di antaranya adalah: a) Dapat berkesan dengan kuat dan kata yang dipakai tahan lama dalam ingatan pemelajar. Disamping merupakan pengalaman yang menyenangkan, pemelajar yang melihat role play juga belajar mendengarkan; b) Sangat menarik bagi siswa, sehingga memungkinkan kelas menjadi dinamis dan penuh antusias; c) Membangkitkan gairah dan semangat optimisme dalam diri pemelajar serta menumbuhkan rasa percaya diri. Pemelajar dapat terjun langsung untuk memerankan sesuatu yang akan di bahas dalam proses belajar bahasanya.

\section{KESIMPULAN}

Dari penjabaran di atas proses pembelajaran dilaksanakan menyesuaikan kebutuhan pembelajar berkaitan dengan kehidupan sehari hari. Pengajar hendaknya mengatur strategi untuk menghadirkan 
konteks Indonesia dalam mengajar BIPA di luar negeri karena hal ini sangatlah penting. Hal ini dilakukan agar konsep dan struktur bahasa Indonesia yang dipelajari dapat digunakan sesuai dengan konteksnya. Salah satu hal penting yang perlu pengajar sadar ketika mengajar BIPA di luar negeri adalah tidak hanya mengajarkan bahasa Indonesia secara teori, tetapi juga bagaimana berbahasa Indonesia yang komunikatif. Hal ini memang tidak lepas dari kaidah kebahasaan. Namun semuanya tidak lepas dari kebutuhan pembelajar dan tentunya berdasarkan pemetaan kompetensi yang telah dibuat. Rencana yang baik akan mempermudah bagaimana proses pelaksanaan pengajaran BIPA di luar negeri. Kegiatan-kegiatan yang dapat dilakukan pengajar BIPA akan berpengaruh dalam rangka mengembangkan BIPA di dunia internasional. Menjadi pengajar BIPA tentu bukanlah tanggung jawab yang ringan, perlu adanya pengalaman ke-BIPA-an agar dapat mencapai tujuan BIPA, sehingga Pengajar BIPA sungguh memperkenalkan Indonesia kepada masyarakat internasional. Dengan demikian, orang asing yang mempelajari bahasa Indonesia akan semakin memahami masyarakat dan budaya Indonesia secara lebih komprehensif yang pada akhirnya dapat meningkatkan rasa saling pengertian dan saling menghargai sehingga makin meningkatkan pula persahabatan dan kerja sama antarbangsa..

\section{DAFTAR PUSTAKA}

Andika, Eko Prasetyo (2015) Pengembangan Bahan Ajar Bipa Bermuatan Budaya Jawa bagi Penutur Asing Tingkat Pemula. Skripsi: Tidak Diterbitkan. Semarang: Universitas Negeri Semarang.

Muliastuti, Liliana (2010) Pengembangan Materi Ajar Bahasa Indonesia Bagi Penutur Asing (BIPA). Disampaikan dalam Konferensi Internasional Pengajaran Bahasa Indonesia Bagi Penutur Asing, 29-31 Juli 2010 di Universitas Indonesia. Hadfield, Jill. 1986. Classroom Dynamic. New York: Oxford University Press 